\title{
Do Ten-year-old Children in Sweden Know How They Learn? A Study of How Young Students Believe They Learn Compared to Their Learning Styles Preferences
}

\author{
Lena Boström ${ }^{1}$ \\ ${ }^{1}$ Associate Professor, Department of Education, Mid Sweden University, Sweden \\ Correspondence: Lena Boström, Department of Education, Mid Sweden University, Universitetsbacken 1, 871 \\ 88 Härnösand, Sweden. Tel: 46-6118-6263/46-702-199-880. E-mail: lena.bostrom@miun.se
}

Received: July 9, 2012 Accepted: July 23, 2012 Online Published: August 23, 2012

doi:10.5539/ies.v5n6p11 URL: http://dx.doi.org/10.5539/ies.v5n6p11

\begin{abstract}
Students' individual learning strategies have been identified as important skills in order to succeed in school as well as important for lifelong learning. The Swedish steering documents are permeated by an epistemological and a methodological variation based on the individual student's learning. Learning how to learn has been identified by the EU as one of eight key competences. There is not much research on elementary school students and meta-learning. This study is therefore aimed to examine these students' own perceptions of their learning, and compare how student think that they learn to their learning styles preferences according to the learning styles assessment Learning Styles Inventory (LSI). The theoretical framework is based on previous Swedish research and Dunn's Learning Styles Model. A multi-method design was selected. After the LSI-test the students estimated their preferences. Finally, interviews were conducted with 15 students. When comparing students' learning styles profiles to their estimation of how they thought they learn, there was a clear discrepancy. The students estimated more preferences than was evident in the analysis. This applies above all to the perceptual strengths, and time of day. The smallest difference, however, was found in the environmental elements. The interviews showed that students have difficulties explaining how they learn. What the students pointed out, however, was their need to work in peace, learning by reading and working on the computer, and also varied learning environments. Their response on learning showed that they were building their insights on the school context and experience from there.
\end{abstract}

Keywords: meta cognition, ten- years-old students, learning preferences, elementary school, perceptions

\section{Introduction}

The teacher must begin by finding out what children's learning looks like in order to understand how children learn (Pramling, 1986). To be able to develop an understanding of their personal learning, to learn how to learn, is an invaluable skill. In order to be able to support students in lifelong learning and to support meta-learning, it is important to begin by acquiring knowledge of how children think that they learn and how they actually learn individually and successfully, to get perspective on their learning. Based on students' strengths and needs (learning strategies), teachers and parents can take care of and stimulate each child's individuality and encourage their optimal learning and growing for life. To promote the desire to learn and give students tools with which they can create their own learning strategies and gain self-awareness, is one of the teacher's most important tasks. Furthermore, it is essential that teachers understand students' individual learning when classes seem to be increasing in diversity.

There are studies of Swedish preschool children's perceptions of their learning, but not much has been carried out on students in primary school. In addition, when the didactic how-question has been researched, which may relate to how education is built up and how student and teachers think about a particular issue, the most dominate perspectives are activities and education (Hartsmar \& Jönsson, 2010). These researches state there is an object of learning and there is an act of learning, and when the subject of learning is discussed and problemized it is mostly based on the best way to help the child understand the object of learning, rather than based on who or what children you are working with and why the selected content is important for them right here and now. 
The present study is based in part on the students' own statements on how they think they are learning via semi-structured interviews, but also in estimates of how they learn compared to their individual learning styles profiles. There is plenty of research on children's/students' learning in preschool, school and at university, but there is no Swedish research on the learning experiences of primary students, and no research on how students estimate their learning compared to their learning styles profile. In order to fill this void, this study focuses on the act of learning at school. For students it is important in an early age develop meta cognitive skills for life-long learning.

This article is based on a feasibility study (Boström, 2012) of an environment built for students' learning styles traits with regard to environmental preferences. It is structured as follows: first, there is a research background of student experienced learning and metacognition, followed by a description of learning styles in general and Dunn's Learning Styles Model in particular to smoothly transfer over to metacognition and self-regulated learning. After a review of the research methods, results, analysis and discussion follow.

\section{Research on Young Students' Learning in a Swedish Context}

This section briefly describes research in Sweden on students' own perceptions of their learning and the concept of metacognition, which basically means "awareness of learning processes".

Research on children's own descriptions of how they learn in a Swedish context is found mainly in Pramling $(1983,1986)$ and her co-researchers (Doverborg, Sheridan, Mårdsjö Olsson). The population which they have chosen to focus on is mainly pre-school children up to eight years old. Pramling's study from 1983 illustrates children's thoughts on learning and that they find it difficult to express what learning means. Children's responses on how they believe how to learn what's new, seems to be linked to what they have learned. Learning by doing, knowing and understanding are the categories Pramling has arrived at. She points to three subcategories: learning by action, by growing older, and by experience.

Scherp and Scherp (2002) also emphasize the importance of students' participation in the curriculum. The content must be related to students' previous ideas so that they will be better able to understand and develop their learning. The teacher's skills play an important role in this respect because they are the strongest influence factors in students' learning (Hattie, 2009, Sylwester 1997).

Doverborg and Pramling (1995) show that good learning conditions have been achieved by starting out in children's everyday problems and situations where children's own thoughts have been given room. Furthermore, Pramling Samuelsson and Sheridan (2006) point out that teaching and learning must not be the focus, but the children's experiences from their environments which create meaning and sense in the child's learning. The child must above all learn about themselves and their world, rather than there is something to be learned. The authors also highlight the importance of the context of the knowledge, what is learned in its context. Pramling Samuelsson and Mårdsjö Olsson (2007) believe it is important for children to have many different experiences because it is through these experiences that children are able to create an understanding of something. Doverborg and Pramling (1995) emphasize that the experiences of each child are unique for that child. When children know how they think and how they perceive their world, they perform their actions with more awareness (Pramling Samuelsson \& Mårdsjö Olsson, 2007). Children should also take part of the thoughts of others to become aware that there are different ways to think.

Knowledge on how students perceive both their own learning as well as how they perceive their surroundings is also needed. They learn by concretion, interaction, communication, action, imitation, to perceive the world with their minds and intelligibility (Pramling Samuelsson \& Sheridan, 2006). Students' metacognitive knowledge and skills are critical for their ability to learn. Awareness of their own learning approaches develops strategies for lifelong learning. This seems to be particularly important competence for reading comprehension (OECD, 2010) (Note 1).

It is also important to find out about children's thoughts about specific content and phenomena. Numerous studies on various subjects (reading, writing, arithmetic, mathematics, history, image) are presented in several studies, with reports of variations in the child's individual understanding of learning objects (Hartsmar \& Jönsson, 2010).

Teachers' attitudes and skills are very important for the students' meta-learning and development (Pramling Samuelsson \& Sheridan, 2006; Stewart \& Landine, 1995) about the goal is to create a stimulating and challenging environment for each child. The teacher's task is to make the learning process visible to the student by asking the student reflective questions about what they learn and how they learn something (Doverborg and 
Pramling, 1995). It is important that teachers build on students' interests and their own initiatives (Skolverket, 2011).

Hartsmar and Jönsson (2010) have in their research followed and interviewed preschoolers and school age students and they describe, in the systematic review, the students' own views. Building upon students' experiences, could both involve the teacher on a comprehensive level and based on a variety of sources he or she will be able to create an understanding for the different circumstances of the students in that group and the diverse experiences and needs that are a result of each student's circumstances.

How students perceive the school as a learning environment, what a "good teacher" is, and how and when student learn best has been researched by Strander \& Torstensson-Ed (2000). Their results describe the importance of making school and preschool enjoyable, and that the children's own initiative and personal responsibility is important for them personally. These are keys for meaningful learning, some of which can be conveyed by explaining the personal system as well as thoughts and how something is learned. Also Liberg (2003) emphasizes the concept of meaning in research on students' learning. Meaning is created in different ways and we create meaning by using different senses. Another perspective on how students learn is research on the school as a discursive practice, in which ideas are created on how children learn. Codes and genres are more or less hidden in the "game" going-to-school is played (Hundeide, 2009).

In conclusion, the Swedish research describes the conditions for students' learning rather than how learning actually accomplished from the students' own perspective.

\section{Theoretical Framework}

\subsection{Learning Styles}

Learning styles is a collective term for theories on how people learn best. There are many different theories and models of learning styles (e.g. Curry's, Dunn \& Dunn's, Gregorc's Kolb's and Vermont's) with different dimensions and variables. They focus on different aspects: cognitive processes, skills, sensory modalities, the process of learning, thinking styles and so on. In theories of learning styles it is simply assumed that everyone can learn, albeit in different ways and on different levels. The area is comprehensive and addresses individual and group level, as well as entire organizations. In Scandinavia, the two best known and most frequently used models are Kolb's Learning Styles Model, which describes the information processing and is frequently used as a starting point in problem-based learning (Hård af Segerstad, Klasson \& Tebelius, 1996), and Dunn's Model, which is multidimensional and widely used in both child and adolescent school in adult education (Boström \& Lassen, 2006; Lauridsen, 2007).

Learning styles can be defined in different ways depending on the focus of the learning process, but overall it is about how people learn individually and what is important for learning to come naturally (Cools \& Rayner, 2009). Learning styles may include more than 70 different models with conflicting assumptions about learning, and with different designs and starting points (Coffield, Ecclestone, Hall \& Moseley, 2004). The learning styles theory can be implemented in schools with parents, students and staff in collaboration (Riding \& Rayner, 1998; Dunn \& Griggs, 2007). This can include the methodical match to students' learning styles, training for parents to better help their child or staff development to better match various classes.

\subsection{Dunn's Learning Styles Model}

Dunn's learning styles model is probably the most internationally widespread, researched and practiced learning styles theory (Buli-Holmgren, Guldahl \& Jensen, 2007; Lauridsen, 2007). It focuses on the elements that are vital when learning that which is difficult and new. Learning styles preferences is a combination of both biological and learned patterns, which means that identical methods, environments and materials are effective for some individuals but ineffective for others (Thies, 1999-2000). Most people have learning styles preferences, but the individual style features are significantly different. Style features vary depending on academic achievement, gender, age, culture, and information processing. Research has shown that there are differences in the stylistic features between high and low performing students, boys and girls and among some cultures. Students who do well in school, so-called "high-achievers" have more dominant perceptual preferences; they prefer learning alone, has a great need of a teacher, are in need of silence, formal furniture and lighting, while the so-called "low achievers" are tactile or kinesthetic dominant, global in brain processing, have a need of sound, informal seating and dim lights. However, the individual differences between individuals are greater than between different groups (Dunn \& Griggs, 2007).

Fifty years of research have shown that there are twenty different elements that have an objective and measurable impact on learning (Dunn \& Griggs, 2007). These twenty elements (see Figure 1) have, in 
international research, been demonstrated a statistically predictable significance at the $95 \%$ level. The elements are divided into five areas (stimulus): environmental, emotional, sociological, physiological and psychological elements, which in varying degrees affect each individual. For the student it is very important to become aware of what has an effect on e.g. motivation, concentration, retention and performance, and to be able to match this with the requirements of the learning environment. This model is directly applicable to direct learning situations and should not be confused with psychological models or testing. It is not talents, personalities characteristics or attitudes; the focus is on learning that which is perceived as challenging and new.

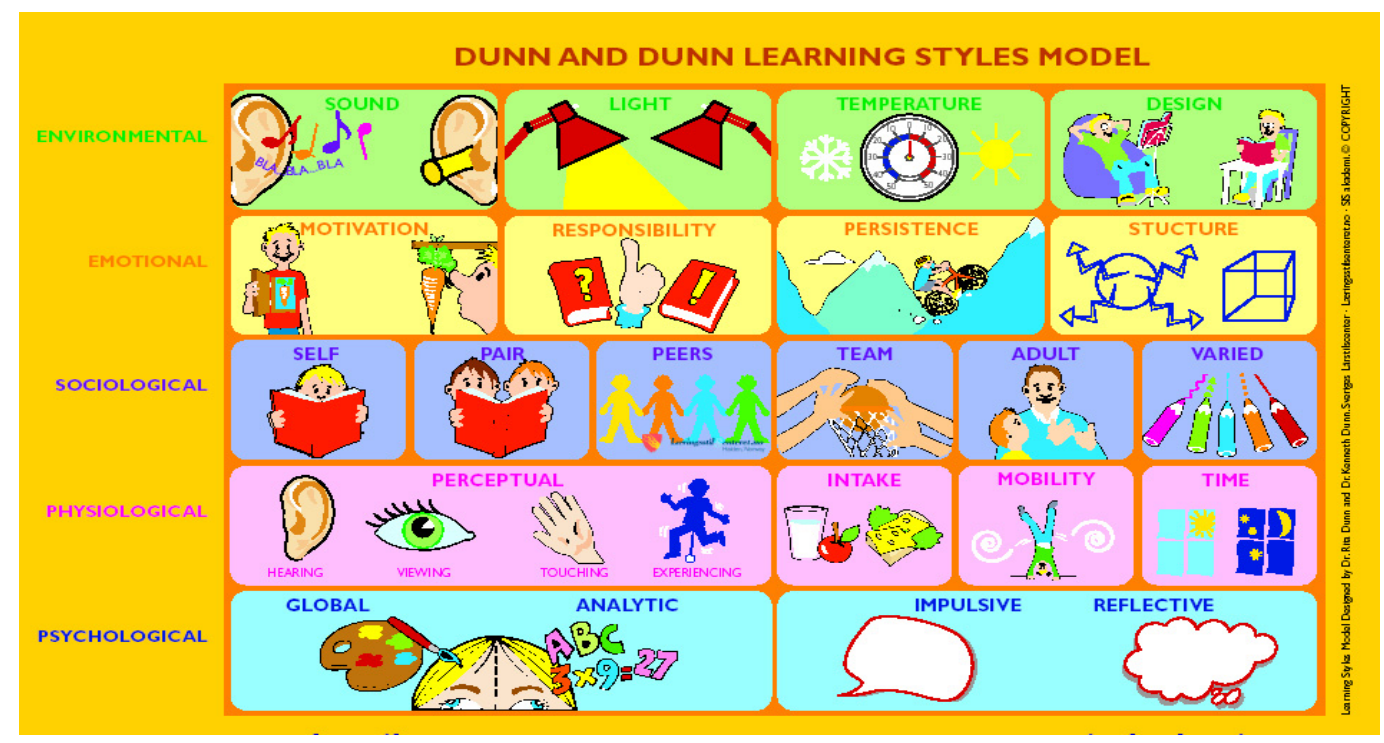

Figure 1. Dunn's Learning Styles Model in Scandinavian design

To date, there are about 900 scientific studies on the Dunn's model. Research on the model and its use is spread over about 130 universities worldwide. This learning styles model has been studied from many different aspects: different types of schools, ages, subjects and populations. Many studies have focused on whether learning styles pedagogy has impact on participants' performance, retention, attitudes and behaviors. Others have focused on meta-learning and school improvement.

There are hundreds of international studies on students aged 7-12 (Dunn \& Griggs, 2007); these studies have different focuses, from matched approaches to international comparisons of learning styles preferences. But there is no study on this model and student's metacognition. However, there are a number of studies on older populations, such as high school students, (Boström, 2004; Boström \& Lassen, 2006) and adults (Sheiring, 1999). When it comes to learning environments and flexible classroom with different mediating learning resources, we find an emerging research and proven experience applicable (Johansson, Carlsson-Skillström \& Ring, 2007; Bergström, 2006; Grysell, 2005).

\subsection{Learning Strategies, Metacognition and Self-regulated Learning}

Learning styles are often added to the concept learning strategies. Finding a definition of learning strategies is no easy task. However, it is frequently emphasized that it is important for students to develop their own learning, that they become autonomous, acquire awareness and good "tools" for lifelong learning, etc. The 2009 PISA report highlighted that students with well-developed ability in self managing their learning, are able to select the appropriate learning outcomes, using their prior knowledge and skills to focus and select useful strategies for different tasks. The report states that "Good learners can apply an arsenal of learning strategies in a flexible manner" (p.77). The report also points out that mastering learning strategies is essential in becoming a good reader.

What are learning strategies? Making a comparison of the concept as it is defined by different researchers, it can be concluded that their definitions differ and that they all place different dimensions in the concept. Learning strategies can be defined as the unconscious or conscious choices of the learner or the teacher. Learning strategies can for example be spontaneous choices and learned or consciously chosen pattern (Hellertz, 1999; Kroksmark, 2003). Oxford (1990) distinguishes between direct and indirect strategies. The former are techniques 
that students use in practice, e.g. memory strategies, cognitive strategies and compensatory strategies. Indirect strategies in this definition are meta cognitive strategies, and emotional strategies. O'Malley and Chamot (1990) make a similar classification of learning strategies with the subgroups cognitive, meta cognitive and socio-affective strategies. Schmeck (1988), however, argues that strategies are conscious choices of the learner in order to implement skills.

The PISA report (OECD, 2010) used the concept of learning approaches and defined three sub-areas; memorization, elaboration and control strategies. The result of this report can be viewed as an extension of what previously students have previously learned of learning strategies. Swedish students' levels in an international perspective regarding a) awareness of effective strategies to understand and remember information, b) awareness of effective strategies to summarize information and c) to use memory techniques and control strategies can be clearly discerned. In all three measured variables of learning strategies, the Swedish students are well below the average of the OECD countries. In conclusion: learning strategies play a critical role in lifelong learning, there is a definition problem, and the Swedish 15-year-olds are below average in regards to the PISA survey.

A result of metacognition is self-regulated learning, which means that the process of taking control of and being able to evaluate the personal learning and behavior which can be used to describe learning that is controlled by metacognition (thinking about thinking), strategic action (planning, monitoring and evaluation personal progress against a standard), and motivation to learn. Self-regulated learning (SRL) emphasizes autonomy and control of the individual that monitors, controls and regulates the actions towards a goal, either information acquisition, to expand expertise and/or self-improvement (Paris \& Paris, 2001). Self-regulated learners are especially aware of their academic strengths and weaknesses, and they have a repertoire of strategies which they are able to apply appropriately to manage the day-to-day challenges of academic tasks.

The process of meta-learning can be stimulated by discussions with peers and teachers, but it also includes the individual student's participation. Meta-learning activities should be included from primary school, first year, because a change in concept formation requires that students reflect on their learning (Liberg, 2003).

\section{Purpose and Method}

\subsection{Purpose}

The purpose of this study was to investigate how students perceive learning and their learning styles preferences. Because the study was conducted in a flexible furnished classroom, different learning styles preferences were made clear for the student. This preliminary study has been limited to the following research questions;

\section{How do young students believe they learn?}

How do young student believe they learn compared to their learning styles preferences?

\subsection{Method}

The study is based on three different empirical materials: 1) Learning Styles Inventory (LSI) (Dunn, Dunn \& Price, 1984, 1991, 2000; Price, 2001) 2) oral estimates and 3) interviews with 15 students. In order to answer the research questions, all students in the three classes took part in the test. They also made a verbal estimation of their learning styles preferences. The students learning styles profiles have then been compared to their estimated preferences. The interviews (15) were interpreted according to a hermeneutical approach.

To find out about the learning styles preferences, the LSI was used, and to gain knowledge about how students think they learn, their interview responses were analyzed. To answer the research questions the empirical material was compiled and compared using both qualitative and quantitative analyzes. The data was collected during the autumn 2011.

The focus of the LSI questions was what respondents considered to be important when they are going to learn something difficult and/or new. The test consists of 110 statements in five gradations. The students grade the statements on a 5-point scale from 1 (definitely disagree) to 5 (definitely agree with). The LSI test is a useful tool for valid conclusions about students' learning styles (Dunn, Griggs, Olson, Gorman, \& Beasley, 1995; Nelson, Dunn, Griggs, Primavera, Fitzpatrick, Bacilious \& Miller, 1993). LSI has high reliability as well as face and construct validity (De Bello, 1990; Tendy \& Geiser, 1998-1999). Only profiles with a consistency score of $<70$ was used and the loss became 4 of 56 students (7\%). Examples of questions can be found in Appendix 1. Response data was processed to obtain an individual mean of 20 elements. The individual profile shows an average for each question on a 60-point scale (see Appendix 2) in the areas of low (averaging 20-40), flexible (mean 40-60) and high (averaging 60-80). As appendix 2 shows, the mean of each stylistic features lies between $20-80$ on the scale, which could mean large and significant differences between students and classes The mean 
for each individual element was then used to obtain a group average. These constitute the basis for the analyses in the studies.

To gain knowledge about how children think they learn, we used semi-structured interviews which were analyzed and interpreted according to a hermeneutical approach.

\subsection{Population and Data Collection}

The survey is based on three classes from different municipalities; there were a total of 56 students. The student catchment area can be characterized as quite "socially stable" with most families living in houses or condominiums. Most of the parents are employed. In one of the schools there are students of many nationalities, in the remaining two schools there were few students of foreign descent. When quoted, the students are identified as (c [nr]).

\subsection{Approach}

The parents were informed about the study and asked about their children's participation. All parents gave their consent in writing. The LSI was completed in school and was processed by the researcher. Two mornings the classes participated in Lärstilslab (the special learning styles classroom). The first morning they were given brief information by the researcher after which the students estimated their learning stylespreferences. They were then allowed to explore the room and work on their geography. The second morning the teacher led the class as they studied geography. This time, five students in each classwere selected for interviews.

\subsection{Ethical Considerations}

The study was performed according to the four ethical principles developed by the Research Council. According to the information requirement all parents were informed of the study's purpose and design and gave their approval in writing. The participants of the study cannot be identified which is in accordance with the confidentiality obligations. Finally, the use requirement has been met by that any material that can be linked to the students has only been used in the framework of the study.

\section{Result and Analysis}

\subsection{Do Ten-years-old Children Know How They Learn? Estimation versus Analysis}

To find out how student think that they learn and how they actually learn according to the LSI, their subjective perceptions were compared to the analytical results. Out of the 20 learning styles elements three of the emotional elements (motivation, conformity and persistence) were deleted. The reason for this is that the emotional elements change from time to time and that these preferences are difficult to measure in this type study.

The students were asked questions about the strengths and the needs of the various elements. Thus, no questions were asked if they were flexible in regards to the different elements. An example of what the questions could be like is the following: If you are going to learn something difficult and new, raise your hand if you enjoy learning in groups. It had been made clear to the students that if they sometimes learned one way, sometimes the other; they should not answer the question. The questions were asked, as mentioned earlier, in Lärstilslab, where the questioner was able demonstrate the informal setting with a sofa and pillows and the formal environment with ordinary school desks.

Figure 1 clearly shows that the student make higher estimations of their strengths and needs (learning styles preferences) than their learning styles profile shows. There are five elements that coincide with the analysis: the need for silence, design, authorities(expert, teacher), routine and variation. Another tendency is that they overestimate their preferences of time and perception in relation to the analysis. 


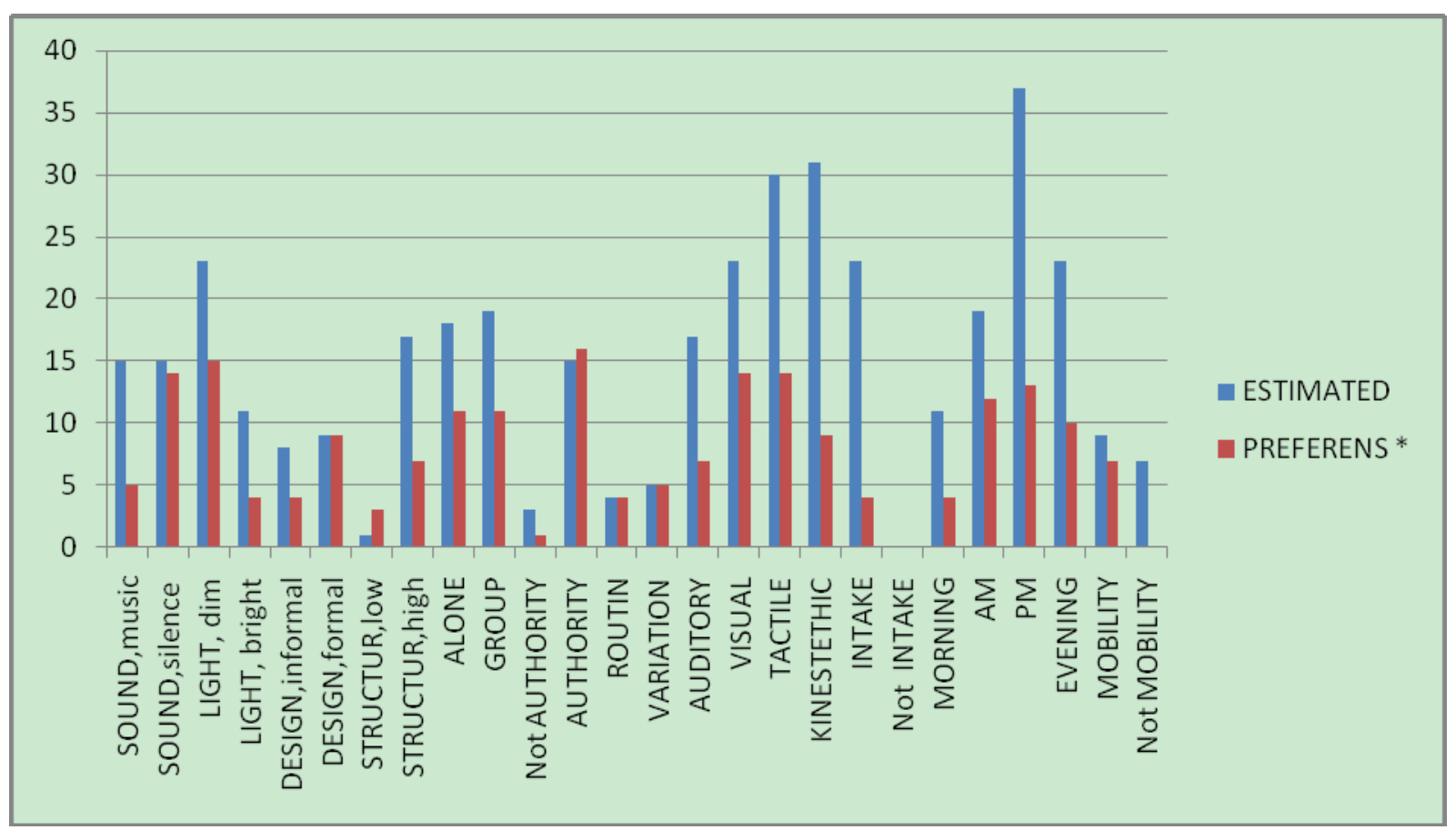

Figure 1. Students' learning styles preferences. Results from LSI and their own estimations

One of the research questions was "Do young students know how they learn?". The answer is yes and no. The comparison of their estimated learning style versus the analysis shows a clear discrepancy. Students overestimate their strengths and needs. There are several possible explanations:

- The questions were asked verbally and only $20 \%$ of the students have auditory strengths. Perhaps the question should have been asked via a different method.

- It was the first time they visited the learning style classroom. The excitement and expectations were high. They may not have been focusing on the issues.

- In some cases there was evidence that the students influence one another during the verbal questions. Friends voted the same and in some cases (e.g. intake) nearly all of the student voted that it was important.

\subsection{Do Young Students Know How They Learn? Interviews}

Fifteen of the students (herein referred to as student (c [nr]) were interviewed using semi-structured questions to gain an insight into their understanding of learning.

\subsubsection{Importance: Calm Working Atmosphere}

The answer to the quite broad question what was important for the student when they learn, was rather similar to the question itself: broad. One aspect seemed a little clearer, namely the need for peace and quiet, in order to learn. Six of the 15 students immediately pointed out that a calm working atmosphere was of outmost importance. They express themselves with words like "not messy"; they need silence to be able to focus. They were able to recognize that talking and running around in the classroom interferes with concentration. Two of the students said it was good if they were able to get up and move. Three students immediately responded to the question with "I do not know." Two students said it was important for them to be able to work with other students.

Otherwise, there were all kinds of answers to this question. These are a few of the respondents' answers:

Sometimes I prefer it if it's quite quiet, sometimes I prefer to listen to music (c 2.)

I have fantasies and see images in my head when I learn (c 5)

It is important that I know what to do, that the teacher says it ... (c 8)

Math is important, you learn to count. READ is also important ... (c 15)

I prefer to do things ... like research (c 2) 
I want to look at what I am going to do and think - look in different books or in the computer (c 4)

I read books, preferably Harry Potter ... (c13)

It is possible to interpret the question in terms of both content and in terms of learning environments and methods. However, this was an open question so it would not be leading.

\subsubsection{The Importance of Perceptual and Sociological Preferences}

To get the students' own words on the perceptual strengths or methodological choices that seem to facilitate their learning, one interview question focused on how best they wanted to learn by examples, e.g. via books, movies, computer, exercises, etc. Also these responses were quite broad, and the students mentioned one or more ways, often commenting that sometimes they learn this way and sometimes that way. A telling quote is the following:

I learn in all sorts of ways ... sometimes when I get to do things, but also with the computer,

and sometimes I want to write or listen ... and I want to read every evening... preferably a

book on horses. (c 10)

Several students are using safety markers in their responses, such as "I believe". The most common response is that they learn through books and computers. Typical responses are:

I think the computer is the best, sometimes I want to read, then I remember well. (c 4)

I'd rather read books with lots of text but also with images ... (c 9)

Reading books is the best for me, like books on animal facts, or crime ... (c 7)

Text or pictures does not matter ... (c 11)

I learn all the time through games, computers, books ... (c 6)

When asked about the sociological preferences the students, answers were quite varied. One third did not know, one third said that it depends and the last third part described what works best for them.

\subsubsection{How do Student Know That They Have Learned?}

The question how students know that they have learned something, was puzzling to them. One of the students immediately responded "That's a good question" (c 9) Three of the students said they had no idea. Five of the students tied the knowledge formation to tests or quizzes, as illustrated by the following quotation:

My head spins and I know, I give the right answers on tests or quizzes ... $\quad$ c 14)

When quizzed, I get high scores.... (c 15)

I do not know, but sometimes I quiz myself what like what's the name of Sweden's largest province, if I know that, I know that I have learned ... (c 12)

Four of the students connect knowledge to improvement: they remember, or they will be able to use knowledge in real life. These are a few of their responses:

You can tell for yourself that you remember, that was it yes... ... In. Something you said or heard, you just realize that you know ... (c 5)

You get better at that thing, don't know ... (c 9)

If I remember you tried to teach us in school and someone asks what it is called (c 3)

\section{Discussion and Conclusions}

The purpose of this study was to begin to research students' learning and learning styles preferences in a context where different learning perspectives were specified. The study could describe what children's learning looks (Pramling, 1986). The study focuses on an individual insider perspective and the act of learning (cf. Hartsmar \& Jönson, 2010) and it was conducted in a physically flexible learning environment.. The students were clearly presented with different preferences for learning and the focus was the students' experiences of their environments that created meaning and purpose in their learning (cf. Pramling Samuelsson and Sheridan, 2006). The special classroom (Lärstilslab) created a contextual framework, and was thus able to provide the students with different experiences in order to create better a understanding (Pramling Samuelsson and Mårdsjö Olsson, 2007). Lärstilslab can also be said to stimulate students' meaning-making through various senses (Liberg, 2003; Strander \& Torstensson-Ed, 2000).

The study was limited to research questions of how ten years old children learn and how they think they are learning compared to their learning styles preferences. To achieve the purpose of the study, students in three 
classes, a total of 56 students, were tested with the LSI, after which the student themselves estimated their learning styles preferences, only strengths and needs were included in the estimation. For two mornings the student visited Lärstilslab to familiarize themselves with this special classroom. Interviews were also conducted with 15 students.

\subsection{Difficult to Know How to Learn}

According to Pramling's 1983 study, preschool children find it difficult to put how they learn into words. This was also hinted at in this study where primary school children were studied. The question is how they could possibly be able to put something into words that they have not learned the words for, and may not have been trained in.

The results of the interviews with the students are characterized by few specific descriptions of their learning. The students' statements are often characterized by safety markers. The student often based their assumptions on what they knew, i.e. that they believed they learn best through books and to some extent though computers. When asked about the external environment, it was expressed quite clearly by many students that peace and quiet in the classroom was something they desired. Six of the students said the environment in general did not matter, while five of the students' described a so-called global environment, i.e. an informal seating with soft lighting and surrounding sounds. Given that a majority of students this age have global preferences (Dunn \& Griggs, 2007), these probably derive from students' own experiences. However, in their answers there is no noticeable trace of the inspirational classroom with all the available exciting material (cf. Johansson et al., 2007; Bergström, 2006; Grysell, 2005). The students have been in contact with the importance of external environment, but it is not accentuated in the interviews.

Comparing the students' learning styles profiles and their estimation of how they think they learn, there is a clear discrepancy. They estimate that they have more need of most of the elements in Dunn's learning styles model than suggested in the analysis. This applies above all to the perceptual strengths, i.e. through which senses they learn best, and at what time of day. However, the smallest difference is found in the environmental elements.

If the results of this study are seen from a cognitive perspective, it is possible to detect an active and constructive process of concept development. Prior to the Lärstilslab visit, the students had come into contact with learning preferences, which was noticeable in their choice of words when talking about for example the environment. Their understanding of this approach depends on previous experiences. This is clearly visible in the responses to the questions How do you know that you have learned something? and How you learn best? The students refer to the context of school, that tests show what they have learned and that they learn well by reading books. Of great importance is the child's meta cognitive ability (Williams, Pramling \& Sheridan, 2000) and some of the students thought in terms of how they learned to learn.

They probably have more experience of the study environments at home and at school and are therefore able to make better estimations in this area. It is based on practice as well as experience. The best time to learn should therefore also have been easy to estimate. In this regard, the students overestimated the afternoon as the best time for learning. By contrast, to know with which sense they are best able to learn can be both abstract and difficult to connect to reality. There was a large margin of error in the environmental estimations made by the children.

Seen from a socio cultural perspective, the results clearly describe the relationships between individuals and the traditions they participate in. The students are shaped by participation in cultural activities such as the use of the tools the culture provides (Säljö 2000). Mediating tools and context is emphasized in this perspective. The mediating tool in this context is the environment itself with all its artifacts, but also the various methods available can be considered as tools. Lärstilslab provides an environment with additional mediating tools (e.g. different types of methods) and situations in which individuals learn (Dysthe, 2003), making it possible to study many elements of the learning process in this context.

Another aspect of the socio-cultural perspective (Säljö, 2000; Dysthe, 2003), is that the student has formed opinions and prejudices about how they think they learn or how they think it should be. The students sometimes grouped themselves with one or more friend, when estimating their learning styles preferences. Research based on the interviews also show that the student has established an idea of their own abilities or lack of ability at an early stage and also what reading and writing means (Doverborg \& Pramling Samulesson, 2000).

The question of how they knows that they have learned something created some confusion, and many of the answers that emerged show that students believe that they have learned if they can show it on a test in school, but some of them also described that they remember things. This could possibly be attributed to the discursive practice that school implies (Hundeide, 2009). 


\subsection{Learning Styles and Metacognition}

This is also a study about students' insights into how they learn to learn - a kind of metacognition. The study shows that ten-year-old students find it difficult to explain and know how they learn. Educational discussions with students about learning takes time and the students have a need for words to describe their insights. Helping students to an understanding of what they learn is one task for schools and teachers; this is a beginning to that end. However, there is some confusion regarding the vocabulary for learning (cf. Boström \& Lassen, 2006), and this should be considered and thoroughly researched.

Discussions about how to learn and how you know you have learned should perhaps be carried out in relation to goals and individual development. Students' learning might be more practical then, in addition, it could make the "road" to learning clearer. In relation to the 2009 PISA report, this area should be developed for Swedish students as they have a quite low placement in an international comparison. A good way to start is to talk about individual learning, it could be a step in the right direction.

\subsection{Practical Implications}

Students are all different and so are teachers. But how much do teachers know about the individuals and the classes they encounter? There are big individual differences. And how are teachers to become able match the individual strengths and needs and the class as closely as possible? Students' understanding of their learning is also an important aspect. If they know how they learn, they are better able to create constructive learning strategies which are what the OECD report requests.

Students need to have a basis for meta-learning, and this should take its starting point in their experiences, meaningfulness and communication with other students with specific concepts. A broad awareness about how students learn and construct their own learning at this age could begin with the concepts act, know and understand (Pramling, 1986) and should provide students with plenty opportunities for reflection and discussion. Another way is to use ideas from the Dunn learning styles model and construct a "learning classroom". The students would then be able to find out what feels best and what results in the most successful learning. A result of this is that teachers must be given more opportunities to broaden their methodological repertoire in the classroom in order to clarify the different types of learning.

\subsection{Continued Research}

Since this area is relatively unexplored in the Nordic countries, this initial study has lead to more questions than answers. The next step may be to compare the experimental group and a control group. Other important issues to consider are how students are able to use their skills at home and how meta cognitive ability is developed in this type of learning room. To connect to the PISA report (OECD, 2010), it is possible to examine successful learning strategies in this environment? New technology and new media has its own writing research in this area. As for learning styles in general there are still many unexplored areas.

\section{References}

Bergström, E. (2006). Förskoleklassen. Stockholm: Fortbildning i Stockholm.

Boström, L., \& Lassen, L. (2006). Unraveling learning, learning styles, learning strategies and meta-cognition. In Education + Training, 48(2/3), 2006, (pp. 178-189). http://dx.doi.org/10.1108/00400910610651809

Boström, L. (2004). Lärande \& Metod. Lärstilsanpassad undervisning jämfört med traditionell undervisning $i$ svensk grammatik. (Dissertation). Jönköping: Högskolan för lärande \& kommunikation i Jönköping \& Helsingfors Universitet). Retrieved from http://urn.kb.se/resolve?urn=urn:nbn:se:hj:diva-13009

Boström, L. (n.d.). Lärstilslab - ett rum för att hitta sitt bästa sätt att lära. En förstudie om några lärstilsaspekter. Rapport, Mid Sweden University

Buli-Holmgren, J., Guldahl, T., \& Jensen, R. (2007). Refleksioner om opplcering - $i$ et laeringsstilsperspektiv. Oslo: Cappelen Damm.

Coffield, F, Ecclestone, K, Hall, E., \& Moseley, D. (2004). Learning styles and pedagogy. A systematic and critical review. Learning \& Skills research centre. Retrieved May 10 from www.lsrc.ac.uk. http://hdl.voced.edu.au/10707/69027

Cools, E., \& Rayner, S. (2009). Research Style: More of the Same or Moving Forward. In S.Rayner \& Cools, E. Style Differences in Cognition, Learning, and Management. Theory, Research and Practice. NY; Routledge (pp. 295 - 306). 
DeBello, T. (1990). Comparison of eleven major Learning Style models; Variables, appropriate population, validity of instrumentations and the research behind them. Journal of Reading Writing and Learning Disabilities International, 6(3), 203-222. New York: Hemisphere. http://dx.doi.org/10.1080/0748763900060302

Doverborg, E., \& Pramling Samuelsson, I. (2000). Att förstå barns tankar. (3:e rev.Uppl.). Stockholm: Liber.

Doverborg, E., \& Pramling, I. (1995). Mångfaldens pedagogiska möjligheter. Stockholm: Liber.

Dunn, R., \& Griggs, S. (2007). Synthesis of the Dunn and Dunn Learning Style Model: Who, What, When, Where, and So What? NY: St. John's University, Center for the Study of Learning and Teaching Styles.

Dunn, R. Dunn, K., \& Price, G. E. (1984, 1991, 2000, 2001). Productivity Environmental Preference Survey. Lawrence, KS: Price System.

Dunn, R., Griggs, S. A., Olson, J., Gorman, B., \& Beasley, M. (1995). A meta analytic validation of the Dunn and Dunn Learning Style model', Journal of Educational Research, 88(6), 353-364. Retrieved from $\mathrm{http}: / /$ search.ebscohost.com/login.aspx?direct=true\&db=afh\&AN=9510112847\&site=ehost-live

Dysthe, O. (2003). Dialog, samspel och lärande. Lund: Studentlitteratur.

Grysell, T. (2005). Den fysiska lärandemiljön. Skriftserie från Universitetspedagogiskt centrum. Umeå; Umeå Universitet.

Hartsmar, N., \& Jönsson, K. (2010). Lärandets vem, varför, vad och hur i förskolan och grundskolans tidiga år. I Skolverket Perspektiv på barndom och barns lärande. En kunskapsöversikt om lärande, (pp 112 - 173).

Hattie, J. A. C. (2009). Visible learning: a synthesis of over 800 meta-analyses relating to achievement. London: Routledge.

Hellertz, P. (1999). Kvinnors kunskapssyn och lärstrategierr. En studie av tjugosju kvinnliga socionomstuderande. Örebro Universitet. Institutionen för socialt arbete. Örebro studies 17.

Hundeide, K. (2006). Sociokulturella ramar för barns utveckling - barns skilda livsvärldar. Lund: Studentlitteratur.

Hård af Segerstad, H., Klasson, A., \& Tebelius, U. (1996). Vuxenpedagogik - att iscensätta vuxnas lärande. Lund: Studentlitteratur.

Johansson, Skillström-Carlsson och Ring. (2007). Ett klassrum som lockar. Klassrumsmiljö utifrån lärstilar Stockholm; Serholt

Kroksmark, T. (2003). Personlig kommunikation. Augusti 2003.

Lauridsen. (2007). Fokus på lcering: København; Akademisk Forlag

Liberg, Caroline. (2003). Flerstämmighet, skolan och samhällsuppdraget. I: Utbildning och demokrati. Tidskrift för didaktik och utbildningspolitik, 12(2), 13-29.

Nelson, Bernie Dunn, Rita, Griggs, Shirley, Primavera, ... Rodney. (1993). Effects of Learning Style intervention on college student's retention and achievement. Journal of College Student Development, 34(5), 364-369. Retrieved from http://www.eric.ed.gov/ERICWebPortal/detail?accno=EJ472308

O’Malley, J. M., \& Chamot, A. (1990). Learning Strategies in Second Language Acquisition. Cambridge: Cambridge University Press.

OECD. (2010). PISA, (2009). Results; Learning to learn. Students' engagement, strategies and practices. $\begin{array}{llllll}\text { Volume III. Retrieved } & \text { May } 15 \text { from www.oecd.org/edu/pisa/2009 }\end{array}$ http://www.oecd.org/pisa/pisaproducts/48852630.pdf

Oxford, R. (1990). Language Learning Strategies: What every teacher should know. Rowely, Mass: Newbury House.

Paris, S., \& Paris, A. (2001). Classroom Applications of Research on Self-Regulated Learning. Educational Psychologist, 2, 89-101. Retrieved from http://search.ebscohost.com/login.aspx?direct=true\&db=afh\&AN=4758323\&site=ehost-live

Pramling Samuelsson, I., \& Mårdsjö Olsson, A-C. (2007). Grundläggande färdigheter-färdigheternas grundläggande (2: a rev. uppl.). Lund: Studentlitteratur

Pramling Samuelsson, I., \& Sheridan, S. (2006). Lärandets grogrund (2:a rev. uppl.). Lund: Studentlitteratur. 
Pramling, I. (1983). The child's conception of learning. (Dissertation). Göteborg: Acta Universitatis Gothenburgensis. Retrieved from http://gup.ub.gu.se/publication/102000-the-childs-conception-of-learning

Pramling, I. (1986). Barn och inlärning. Lund: Studentlitteratur.

Riding, R., \& Rayner, S. (1998). Cognitive Styles and Learning Strategies. Understanding style differences in learning and behavior. London: David Fulton.

Schering, M. (1999). The effects of learning-style instructional resources on fifth-grade suburban students' meta-cognition, achievement, attitudes, and ability to teach themselves. NY: (Doctoral dissertation, St John's University).

Scherp, H-Å., \& Scherp, G-B. (2002). Elevers lärmiljö - Lärares undervisning och elevers lärande. Karlstad: Institutionen för utbildningsvetenskap.

Schmeck, R. R. (1988). An introduction to strategies and styles of learning. In R.R. Schmeck (Ed.), Learning Strategies and Learning Style (pp. 3-20). New York: Plenum Press.

Skolverket. (2011). Läroplan för grundskolan, LGR 11, Stockholm: Liber [Swedish National Curriculum $\begin{array}{llllll}\text { Guidelines } & \text { (Steering } & \text { Documents)]. } & \text { Retrieved } & \text { May } & 10\end{array}$ http://www.skolverket.se/kursplaner-och-betyg/laroplaner-kursplaner-amnesplaner

Stewart, J., \& Landine, J. (1995). Study Skills from a Metacognitive Perspective. Guidance \& Counseling; v11 n1 (pp.p16-20) Aut $1995 . \quad$ Retrieved from http://search.ebscohost.com/login.aspx?direct=true\&db=afh\&AN=9512104069\&site=ehost-live

Strander, K., \& Torstenson-Ed, T. (2000). Barnen och Läroplanen: Om barns och vuxnas syn på lärande. Stockholm; LHS

Sylwester, R. (1997). En skola för hjärnan (J. Emt, Trans.). Jönköping: Brain Books.

Säljö, R. (2000). Lärande i praktiken. Ett sociokulturellt perspektiv. Stockholm: Prisma.

Tendy, S.M., \& Geiser, W.F. (1999). The search for style: It all depends on where you look. National Forum of Teacher education Journal, 1, 3-15. Los Angeles: California State University. $\mathrm{http}: / /$ www.eric.ed.gov/ERICWebPortal/detail?accno=ED410029

Thies, Armin P. (1999-2000). The neuropsychology of learning styles. National Forum of Applied Educational Research Journal, 13(1), 50-62.

Williams, P., Sheridan, S., \& Pramling Samuelsson, I. (2000). Barns samlärande-En forskningsöversikt. Stockholm: Skolverket, Liber distribution.

\section{Appendix}

Appendix 1. Questions from the LSI

\begin{tabular}{|c|c|c|c|c|c|c|}
\hline \multirow[t]{2}{*}{ Nr. } & \multirow[t]{2}{*}{ Questions to answer: } & \multirow{2}{*}{$\begin{array}{l}1 \\
8\end{array}$} & \multirow[t]{2}{*}{2} & \multirow{2}{*}{$\begin{array}{l}3 \\
-\oplus\end{array}$} & \multirow[t]{2}{*}{4} & \multirow{2}{*}{$\begin{array}{l}5 \\
\text { (-) }\end{array}$} \\
\hline & & & & & & \\
\hline 1 & I prefer working in bright light. & 1 & 2 & 3 & 4 & 5 \\
\hline 2 & I like to work alone. & 1 & 2 & 3 & 4 & 5 \\
\hline 3 & It is easy for me to concentrate late at night. & 1 & 2 & 3 & 4 & 5 \\
\hline 4 & I like to draw or use diagrams when I work, & 1 & 2 & 3 & 4 & 5 \\
\hline 5 & I often have to be reminded to complete certain tasks or assignments. & 1 & 2 & 3 & 4 & 5 \\
\hline 6 & The one job I like doing best, I like to do with a teacher. & 1 & 2 & 3 & 4 & 5 \\
\hline 7 & I can think better when lying down than sitting. & 1 & 2 & 3 & 4 & 5 \\
\hline 8 & I prefer cool temperatures when I need to concentrate. & 1 & 2 & 3 & 4 & 5 \\
\hline 9 & I like to block out noise or sound when I work. & 1 & 2 & 3 & 4 & 5 \\
\hline 10 & People keep reminding me to complete my work. & 1 & 2 & 3 & 4 & 5 \\
\hline
\end{tabular}


Appendix 2. LSI individual profile

\section{Learning Style Inventory}

Individual Profile
Name: q q
Sex: Female
Date of Printing: 2012-07-31
Year of Birth: $x x x x$
Grade: 10
Identification: $q$

Preference Summary

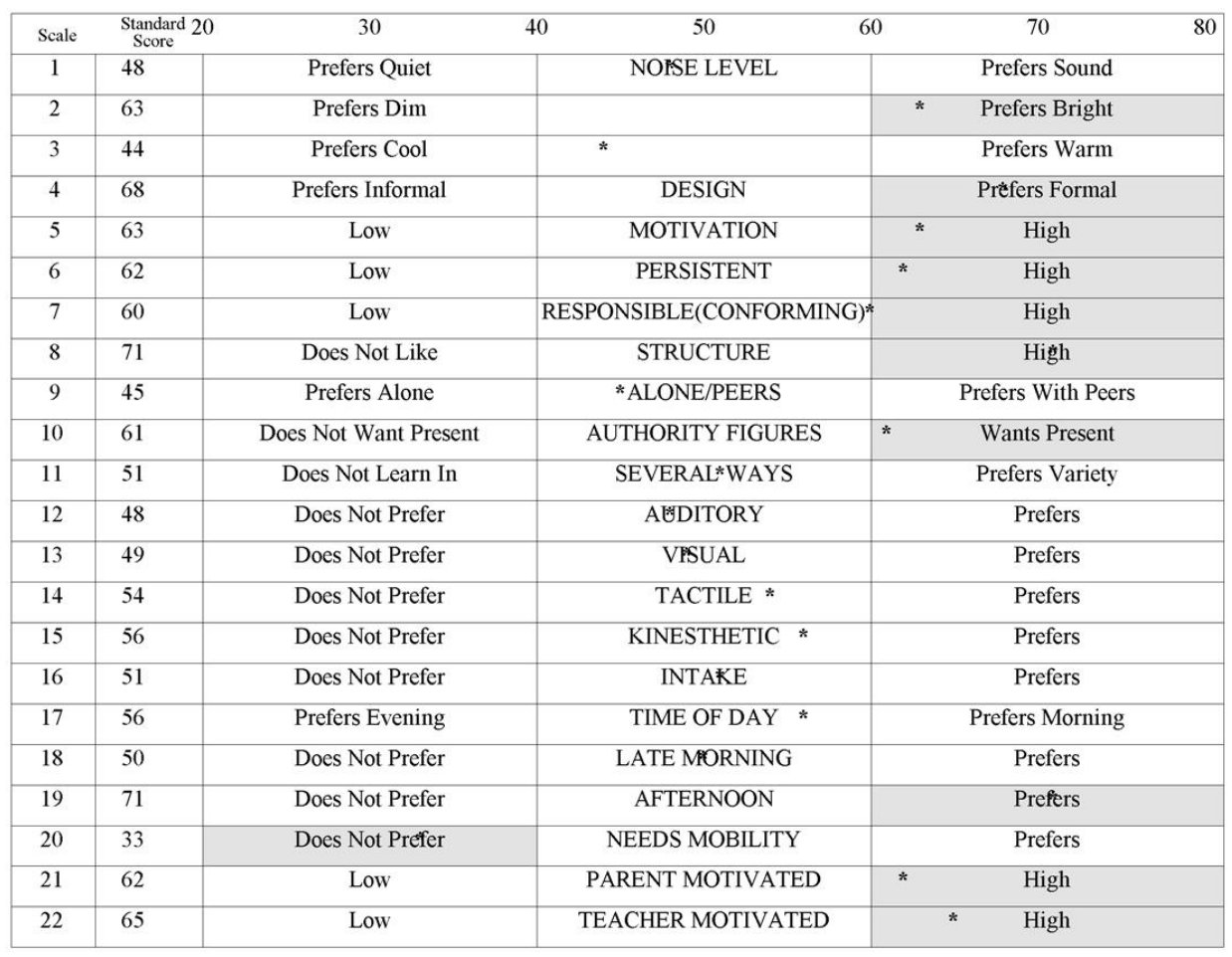

Consistency: $\quad 75$

Price Systems, Inc., Box 1818, Lawrence, KS 66044-1818, USA, (785)843-7892

www.learningstyle.com

Note

Note 1. Organisation for Economic Co-operation and Development (OECD) is an international organization working for cooperation between the industrial countries with democracy and market economy. PISA is an international study that was launched by the OECD in 1997. It aims to evaluate education systems worldwide every three years by assessing 15 -year-olds' competencies in the key subjects: reading, mathematics and science. To date over 70 countries and economies have participated in PISA. 